Article

\title{
Defining Fertilization Strategies for Sorghum (Sorghum bicolor (L.) Moench) Production Under Sudano-Sahelian Conditions: Options for Late Basal Fertilizer Application
}

\author{
Komla Kyky Ganyo 1,2,3,*, Bertrand Muller ${ }^{1,4,5}$, Malick Ndiaye ${ }^{1,2,6}$, Espoir Koudjo Gaglo ${ }^{2}$, \\ Aliou Guissé ${ }^{2}$ and Myriam Adam 4,7,8,9 \\ 1 Centre d'Etude Régional pour l'Amélioration de l'Adaptation à la Sécheresse (CERAAS), BP 3320, Route de \\ Khombole, Thiès, Senegal; bertrand.muller@cirad.fr (B.M.); agromalick@yahoo.fr (M.N.) \\ 2 Département de Biologie Végétale, 10 UMI 3189 ESS, Université Cheikh Anta Diop de Dakar (UCAD), BP \\ 5005, Dakar, Senegal; jspero@mygglo.com (E.K.G.); aliou.guisse@ucad.edu.sn (A.G.) \\ 3 Institut Togolais de Recherche Agronomique (ITRA), BP 1163, Lomé, Togo \\ 4 AGAP, Univ de Montpellier, MUSE, CIRAD, INRA, Montpellier SupAgro BP 34090, France; \\ myriam.adam@cirad.fr \\ 5 CIRADAmpandrianomby, Antananarivo 101, BP 853, Madagascar \\ 6 Institut Sénégalais de Recherches Agricoles (ISRA), CRA de Saint-Louis, Route de Leybar B.P. 240 \\ Saint-Louis, Senegal \\ 7 CIRAD, UMR AGAP, Bobo-Dioulasso, Burkina Faso \\ 8 Institut de l'Environnement et de la Recherche Agricole (INERA), 01BP 910 Bobo Dioulasso, Burkina Faso \\ 9 International Crops Research Institute for Semi-Arid Tropics (ICRISAT), BP320 Bamako, Mali \\ * Correspondence: desireganyo@gmail.com
}

Received: 23 August 2019; Accepted: 28 October 2019; Published: 30 October 2019

\begin{abstract}
Soil nutrient deficiency and rainfall variability impair the production of sorghum (Sorghum bicolor (L). Moench) in Sudano-Sahelian zone. The aim is to study the environmental factors that can determine the effect of fertilizer application on sorghum grain yield and to formulate tailored fertilization strategies according to sorghum varieties (hybrid and open pollinated improved varieties) and environmental context. Field experiments were conducted during the 2015 and 2016 growing seasons in Nioro du Rip and in Sinthiou Malème (Senegal). In a randomized complete block design arranged in a split-plot with four replications, three factors were tested: sorghum genotype (G: Fadda, Faourou, Soumalemba and Soumba with different cycle lengths), environment (E: irrigation and rainfed, different soil types and fertility levels), and fertilization management (M: five different combinations of application dose and application time) including $\mathrm{T} 1=$ no fertilizer applied; $\mathrm{T} 2$ (recommended practice, $100 \%)=150 \mathrm{~kg} / \mathrm{ha}$ of NPK $(15-15-15)$ at emergence $+50 \mathrm{Kg} / \mathrm{ha}$ of urea $(46 \%)$ at tillering $+50 \mathrm{~kg} / \mathrm{ha}$ of urea at stem extension; T3 $=50 \% \mathrm{~T} 2 ; \mathrm{T} 4(100 \%$ delay $)=150 \mathrm{~kg} / \mathrm{ha}$ of NPK $+50 \mathrm{~kg} / \mathrm{ha}$ of urea at stem extension $+50 \mathrm{~kg} / \mathrm{ha}$ of urea at heading ; T5 $=50 \% \mathrm{~T} 4$. Results showed that: (i) in most environments, stressed plants under late application treatments (T4 and T5) recovered biomass once the fertilizer was applied (ii); grain yield with $\mathrm{T} 5$ was higher than with $\mathrm{T} 4$ under well-watered conditions (sufficient and well distributed rainfall and eventual complementary irrigations) ; (iii) Fadda, a hybrid, responded differently to fertilization than the other varieties only for biomass production, (iv) late fertilizer application treatment (T4) gave higher grain yield than the recommended practice (T2) in the environment with low yield potential, and (v) long cycle duration genotypes benefited better from late fertilization compared to short cycle duration genotypes. This study showed that under Sudano-Sahelian conditions late fertilization of sorghum can be beneficial to grain yield if the rainy season has a slow start, depending on sorghum genotypes (i.e., cycle length), and on the initial $\mathrm{N}$ content of the soil.
\end{abstract}


Keywords: late fertilization strategies; environmental conditions; sorghum; Sudano-Sahelian zone

\section{Introduction}

Sorghum (Sorghum bicolor L. Moench) represents a main staple food for millions of people in tropical arid and semi-arid regions of Africa, Asia and South America [1] and is included in most dishes and food products consumed in Sahelian and Sudano-Sahelian zones of Africa. Even though it has been described as a drought tolerant and well adapted crop to tropical and sub-tropical zones [2,3], sorghum cultivation nowadays in Sudano-Sahelian zone comes with low productivity. To overcome this low productivity, plant breeders have developed, during the last decades, viable modern varieties such hybrids and Open Pollinated Varieties (OPV) for different environments [4-7]. However, to achieve high average yields with these hybrids and OPV, adequate farming practices are central to optimize the use of soil water content and inputs of fertilizer [8-10].

According to Hansen [11], climate is the most important factor that governs food production, hence agriculture is considered as the most weather-dependent of all human activities. Sahel is characterized by extreme climate variability, as evidenced by the impacts of the severe droughts in the late 20th century [12]. The severity of climate uncertainties is particularly strong in the Sahel where rainfed agriculture is the main source of food and income $[13,14]$. The main factors that limit crop production in the Sudano-Sahelian zone are soil nutrient deficiency (particularly N deficiency), short rainy season and inter-annual and intra-seasonal rainfall variability, with dry spells occurrence during the crop growing season [15]. According to the Intergovernmental Panel on Climate Change (IPCC) fourth assessment report (AR4, 2007), climate change resulting in an increase of greenhouse gas emissions will accentuate rainfall uncertainty and extreme events such as extreme droughts, flooding, temperature increase in some parts of world. In Africa, climate change and variability will impose additional pressure on water (its availability, accessibility and demand) and mixed rainfed semi-arid systems will be affected in the Sahel, as well as mixed rainfed and highland perennial systems in the Great Lakes region and in other parts of East Africa [16,17]. Both variability and change in climate affect food production, stability of food supplies, food utilization, access to food and food prices across the world [18]. Dealing with the uncertainty of climate is a challenge for agriculture in general and for farmers in particular. Perceiving risks in input investments due to unpredictable weather, farmers in the Sahel are still using little or no fertilizer and local crop varieties, hence maintaining low production level $[13,19]$. However, with the population growth and the increasing demand of food, maximizing crop productivity while minimizing losses and maintaining resilience is a complicated obligation. In this context, proper fertilizer management can be one of the key strategies to optimize crops' yields since nitrogen and water are two of the most important factors for crop production [20-22]. To mitigate the effect of rainfall uncertainty and to cope with the drought spells during the growing season there is a need to consider climate information and forecasts to define fertilizer application time. Numerous studies Sultan et al. [23], Roudier et al. [24] and Sultan and Gaetani [25] indicated that seasonal forecasts could help to provide advises about varieties' choice, sowing date, and inputs management. Roudier et al. [24] showed that (i) predictions of long rainy season duration (onset and offset) and humid years exclude the use of short cycle millet cultivars because of damages occurring on early maturing cultivars and (ii) the impact of fertilizer in humid years is positive on yields in South-West Niger. Therefore, future climate forecasts might help African farmers to take crucial strategic decisions to reduce their vulnerability and increase farm profitability [23].

Delaying fertilizer application according to forecast and observed rainfall might be an appropriate strategy to enhance sorghum grain yield and reduce potential losses in input investments. Results of late fertilizer especially $\mathrm{N}$ applications on crops varied greatly among studies for yield increases and grain quality [26-30]. Some field studies on late fertilization showed promising results. Wuest and Cassman [31] compared the nitrogen uptake efficiency of preplant versus late-season application 
of irrigated wheat and observed a significant increase in yield with late application. Perez et al. [32] reported an increase in rough rice yield by $6 \%$ and head rice yield by $17 \%$ with an additional $\mathrm{N}$ application of $30 \mathrm{~kg}$ of $\mathrm{N} / \mathrm{ha}$ at flowering. Bodson et al. [33] studied the split of $\mathrm{N}$ fertilizer on wheat and found that applying $\mathrm{N}$ fertilizer twice at stem elongation and at flag leaf stages gave similar yields with higher grain quality compared to traditional practice with 3 applications at tillering, stem elongation and leaf flag stages. Furthermore, a number of studies showed the potential of increasing grain yield and grain protein through late-season $\mathrm{N}$ application under rainfed conditions $[34,35]$ and in irrigated conditions $[36,37]$. These authors found that the yield increase with $\mathrm{N}$ late-application depended on the native soil $\mathrm{N}$ supply, previous soil $\mathrm{N}$ uptake, plant developmental stage, and yield potential. In addition, Rötter and Van Keulen [38] reported that the response of different maize genotypes (short, medium, long durations) to fertilization varied according to different rainfall regimes in eight study zones. Yield distributions for the eight sites depended on normal, unfavorable and favorable years. Keating et al. [39] and McCown et al. [40] suggested that farmers would benefit by adjusting cropping practices to rainfed conditions early in the season, i.e., applying fertilizers only in "good" (favorable) seasons.

The objectives of this research were (i) to determine the responses of various West-African sorghum varieties with different cycle lengths to the application of fertilizer (NPK and urea) at selected stages of development according to water regime (different rainfall patterns) i.e., Genotype*Environment ${ }^{*}$ Management interactions and (ii) to define the conditions favoring high grain yield with late-application. It is hypothesized that (1) late fertilization would be beneficial under rainfed conditions with a well rainfall distribution after a slow beginning of the rainy season; that (2) hybrid sorghum is going to respond better to fertilization than open pollinated sorghum varieties and (3) that long cycle varieties will benefit from late fertilization compared with the short season ones because a slow beginning of rainy season might affect more short cycle varieties due to their early maturity.

\section{Materials and Methods}

\subsection{Experimental Sites}

The study was conducted during the 2015 and 2016 rainy seasons in the experimental stations of ISRA (Senegalese Institute of Agricultural Research) of "Nioro du Rip" (13 $\left.44^{\prime} \mathrm{N} ; 15^{\circ} 46^{\prime} \mathrm{W}\right)$ and "Sinthiou Malème" (13 $\left.46^{\prime} \mathrm{N} ; 13^{\circ} 40^{\prime} \mathrm{W}\right)$, both representative of the Sudano-Sahelian climate of Senegal with a mono-modal rainfall distribution from June to October with a peak during the last week of August. While the long-term average seasonal rainfall of the two locations are similar $(790 \mathrm{~mm}$ and $763 \mathrm{~mm}$ for the 1987-2016 period for Nioro du Rip and Sinthiou Malème, respectively), they were quite different during the 2 years of the study: $1045 \mathrm{~mm}$ (2015) and $917 \mathrm{~mm}$ (2016) in Nioro du Rip and $563 \mathrm{~mm}$ (2015) and $553 \mathrm{~mm}$ (2016) in Sinthiou Malème. Figure 1 shows temperatures, cumulative water received (rainfall and irrigation) per decades for the 2 sites (Nioro du Rip, Sinthiou Malème) over the 2 years (2015 and 2016). 

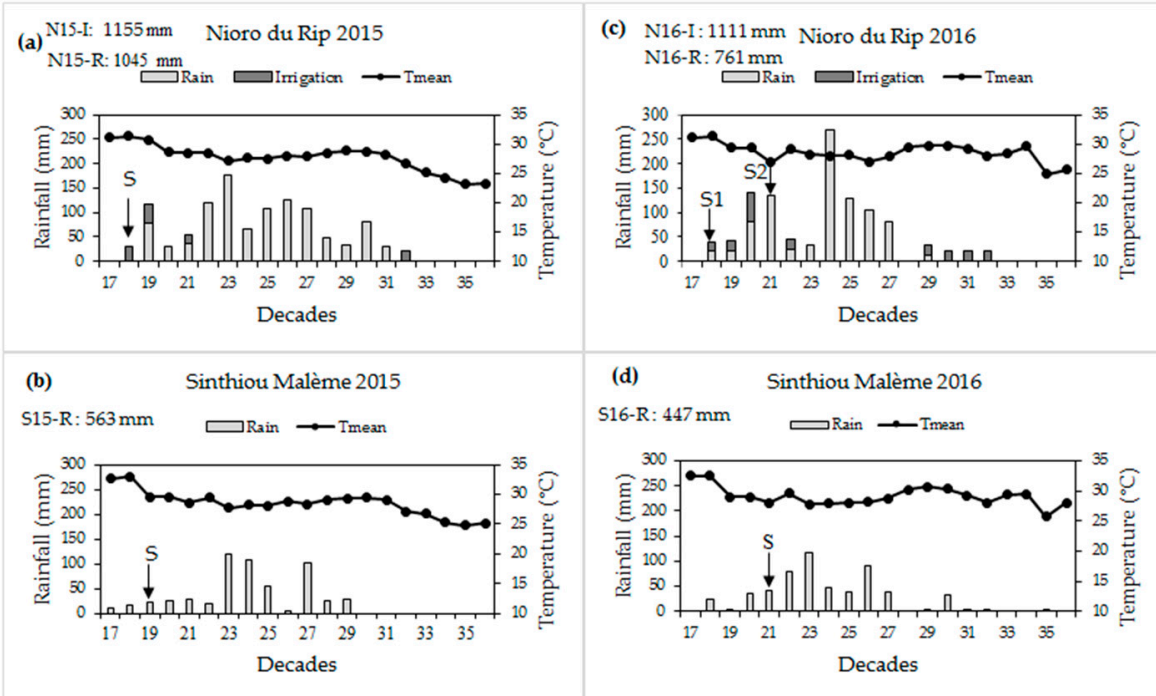

Figure 1. Cumulative water (rain + irrigation), mean air temperatures (Tmean) per decades and sowing date (S) for the 2 locations (a) Nioro du Rip in 2015, (b) Sinthiou Malème in 2015, (c) Nioro du Rip in 2016 and (d) Sinthiou Malème in 2016; N15-I: Nioro du Rip 2015 Irrigated, N15-R: Nioro du Rip 2015 Rainfed, N16-I: Nioro du Rip 2016 Irrigated, N16-R: Nioro du Rip 2016 Rainfed, S15-R: Sinthiou Malème 2015 Rainfed, S16-R: Sinthiou Malème 2016 Rainfed, S: Sowing date, S1: Sowing date 1, S2: Sowing date 2 .

Experiments' soils at Nioro du Rip were sandy for both years whereas at Sinthiou Malème it was sandy in 2015 and sandy loam in 2016 (Table 1). For the two years, experiments were conducted in different locations to avoid residual effect of previous fertilization. For all experiments the previous crop (preceding year) was peanut. Initial conditions on the top $30 \mathrm{~cm}$ of the soil were characterized just before sowing (Table 1 ).

In Nioro du Rip, for both years, 2015 and 2016, we had rain-fed experiments and experiments supplemented by irrigation (sprinkler method) during early and late growing season to maintain well-watered conditions. The irrigated experiments received $110 \mathrm{~mm}$ in four irrigation events in 2015 and $200 \mathrm{~mm}$ in ten irrigation events in 2016 (Figure 1). Irrigations were applied once the soil in the top $15 \mathrm{~cm}$ was dry and plants were withering. At least $30 \mathrm{~mm}$ were applied per week to the crop. After irrigation soil status was close to field capacity for the first $30 \mathrm{~cm}$. In Sinthiou Malème there was no access to irrigation facilities. Experiments will be named and referenced as "Nioro du Rip 2015 Irrigated" (N15-I), "Nioro du Rip 2015 Rainfed" (N15-R), “Nioro du Rip 2016 Irrigated” (N16-I), "Nioro du Rip 2016 Rainfed" (N16-R), "Sinthiou Malème 2015 Rainfed" (S15-R) and "Sinthiou Malème 2016 Rainfed" (S16-R). The sowing date of the second trial at Nioro du Rip in 2016 (N16-R) was delayed about 28 days to diversify water regime. Weeds, pest and diseases controls and ridging were carried out to ensure optimal experimental conditions. 
Table 1. Soil conditions at the beginning of each experiment.

\begin{tabular}{|c|c|c|c|c|c|c|c|c|c|c|c|c|}
\hline Location & Experiments & $\begin{array}{l}\text { Horizon } \\
(\mathrm{cm})\end{array}$ & Clay (\%) & Silt (\%) & Sand (\%) & $\mathrm{pH}$ & Total P (ppm) & $\begin{array}{c}\text { Available P } \\
\text { (ppm) }{ }^{a}\end{array}$ & $\begin{array}{l}\text { Total Carbon } \\
(\%)^{\mathrm{b}}\end{array}$ & Total N (\%) & $\begin{array}{c}\text { Organic } \\
\text { Matter (\%) }\end{array}$ & $\mathrm{C} / \mathrm{N}$ \\
\hline \multirow{12}{*}{ Nioro du Rip } & \multirow{3}{*}{ N15-R } & $0-10$ & 1.45 & 3.43 & 95.12 & 5.78 & 19.88 & 8.686 & 0.636 & 0.052 & 1.10 & 12.19 \\
\hline & & $10-20$ & 5.23 & 3.72 & 91.06 & 5.17 & 10.72 & 4.685 & 0.580 & 0.038 & 1.00 & 15.25 \\
\hline & & $20-30$ & 4.49 & 2.82 & 92.69 & 5.68 & 12.05 & 5.264 & 0.615 & 0.065 & 1.06 & 9.41 \\
\hline & \multirow{3}{*}{ N15-I } & $0-10$ & 1.92 & 3.46 & 94.62 & 6.09 & 15.54 & 6.791 & 0.748 & 0.042 & 1.29 & 17.62 \\
\hline & & $10-20$ & 2.54 & 4.52 & 92.95 & 5.98 & 13.13 & 5.738 & 0.595 & 0.050 & 1.03 & 11.81 \\
\hline & & $20-30$ & 3.95 & 2.84 & 93.21 & 5.94 & 15.78 & 6.896 & 0.636 & 0.049 & 1.10 & 13.07 \\
\hline & \multirow{3}{*}{ N16-I } & $0-10$ & 1.94 & 3.78 & 94.28 & 6 & 10.35 & 4.520 & 0.508 & 0.047 & 0.88 & 11.31 \\
\hline & & $10-20$ & 5.14 & 5.76 & 89.10 & 5.46 & 7.00 & 3.059 & 0.508 & 0.033 & 0.88 & 11.88 \\
\hline & & $20-30$ & 8.31 & 4.90 & 86.79 & 5.54 & 6.29 & 2.748 & 0.457 & 0.046 & 0.79 & 9.85 \\
\hline & \multirow{3}{*}{ N16-R } & $0-10$ & 2.49 & 3.85 & 93.67 & 6.98 & 12.68 & 5.541 & 0.611 & 0.064 & 1.05 & 9.55 \\
\hline & & $10-20$ & 5.16 & 3.73 & 91.11 & 7.01 & 11.97 & 5.231 & 0.536 & 0.046 & 0.92 & 11.76 \\
\hline & & $20-30$ & 8.34 & 4.61 & 87.06 & 6.62 & 13.19 & 5.763 & 0.499 & 0.050 & 0.86 & 10.06 \\
\hline \multirow{6}{*}{$\begin{array}{l}\text { Sinthiou } \\
\text { Malème }\end{array}$} & \multirow{3}{*}{ S15-R } & $0-10$ & 2.71 & 4.21 & 93.08 & 5.69 & 6.79 & 2.968 & 0.411 & 0.040 & 0.71 & 10.36 \\
\hline & & $10-20$ & 2.63 & 4.15 & 93.22 & 5.29 & 6.37 & 2.785 & 0.372 & 0.035 & 0.64 & 10.63 \\
\hline & & $20-30$ & 2.94 & 3.46 & 93.60 & 5.51 & 5.75 & 2.511 & 0.359 & 0.037 & 0.62 & 9.62 \\
\hline & \multirow{3}{*}{$S 16-R$} & $0-10$ & 7.21 & 8.43 & 84.36 & 6.16 & 8.01 & 3.502 & 0.676 & 0.060 & 1.17 & 11.27 \\
\hline & & $10-20$ & 8.10 & 7.94 & 83.96 & 6.76 & 4.16 & 1.818 & 0.583 & 0.053 & 1.01 & 11.04 \\
\hline & & 20-30 & 11.34 & 8.52 & 80.14 & 6.45 & 5.48 & 2.394 & 0.592 & 0.033 & 1.02 & 18.06 \\
\hline
\end{tabular}

a Olsen and Dabin, ${ }^{\mathrm{b}}$ Walkley \& Black, ${ }^{\mathrm{c}}$ Kjeldahl methods. N15-R: Nioro du Rip 2015 Rainfed, N15-I: Nioro du Rip 2015 Irrigated, N16-I: Nioro du Rip 2016 Irrigated, N16-R: Nioro du Rip 2016 Rainfed, S15-R: Sinthiou Malème 2015 Rainfed, S16-R: Sinthiou Malème 2016 Rainfed. 


\subsection{Experimental Design}

The experimental set up was a randomized complete block design arranged in a split-plot with four replications. Treatments consisted of five patterns of fertilization, differing in quantity and/or application timing, combined with four sorghum genotypes. The fertilization treatments were assigned to the main plots. Fertilizers were applied at different growing stages (Figure 2) determined by changes in plant morphology or appearance of new organs (timing differing according to genotype). The genotypes were assigned to the subplots. The six experiments only differed by the randomization of the treatments. The experimental unit (subplot) consisted of five rows of $6.8 \mathrm{~m}$ long with an inter-row spacing of $0.8 \mathrm{~m}$. Five to six seeds were sown in hills spaced at $0.4 \mathrm{~m}$ distance, two plants were left after a thinning done at around two weeks after sowing, giving a density of 62500 plants/ha.

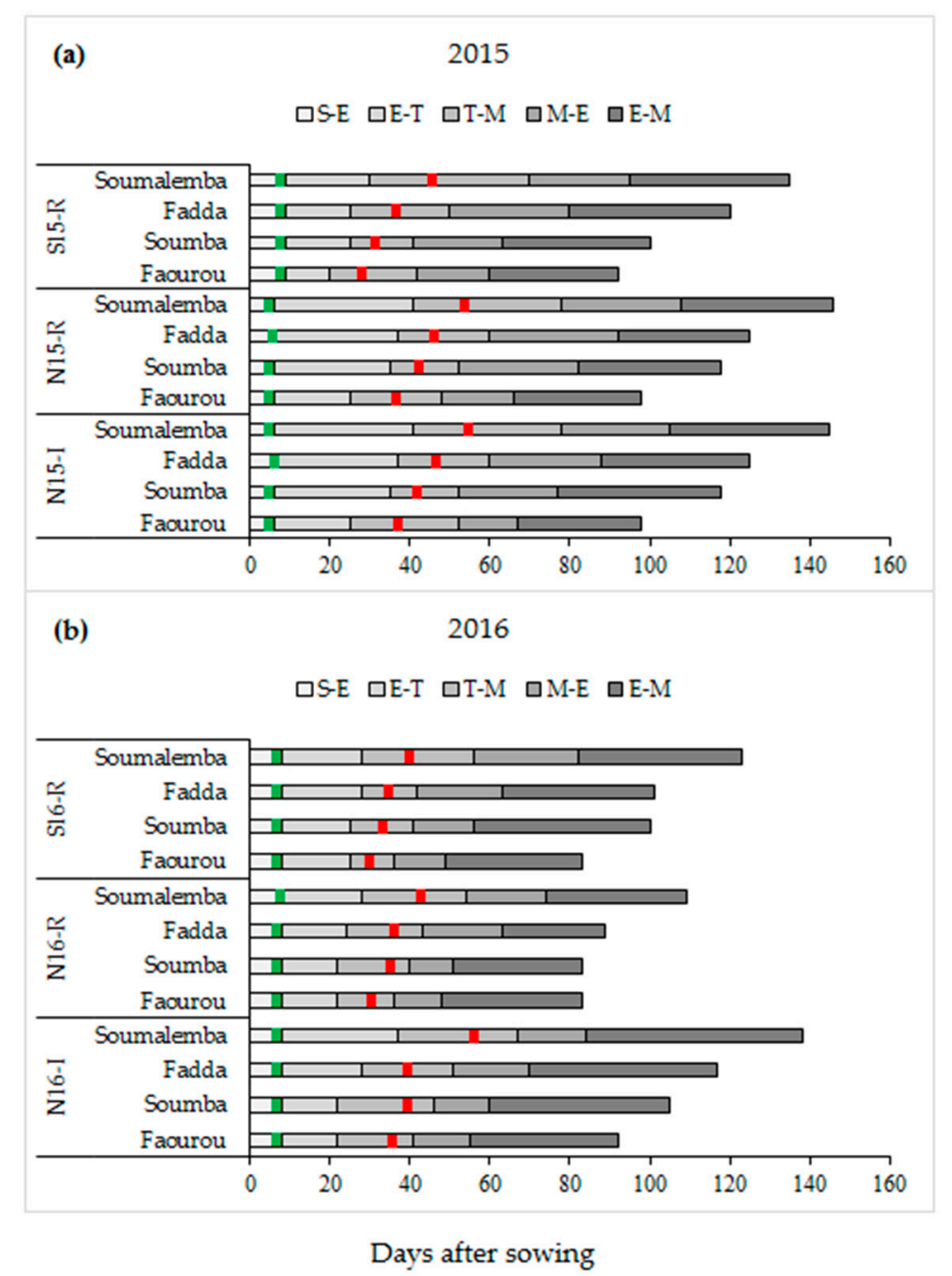

Figure 2. Sorghum genotypes growing stages during the experiments (a) in 2015 and (b) in 2016; Green bar represents the first conventional application date (emergence), Red bar represents the first late application date (stem extension), S-E: Sowing to Emergence, E-T: End Emergence to Tillering, T-S: End Tillering to Stem extension, S-H, End Stem extension to Heading, H-M: End Heading to Maturity, N15-R: Nioro 2015 Rainfed, N15-I: Nioro 2015 Irrigated, N16-I: Nioro 2016 Sowing date 1, N16-R: Nioro 2016 Sowing date 2, S15-R: Sinthiou Malème 2015, S16-R: Sinthiou Malème 2016.

Table 2 showed the "fertilization" modalities. They were (i) T1, no fertilizer applied i.e., $0 \%$; (ii) T2, $150 \mathrm{~kg} / \mathrm{ha}$ of NPK (15-15-15) applied at emergence followed by $50 \mathrm{~kg} / \mathrm{ha}$ of urea (46\%) at tillering and $50 \mathrm{~kg} / \mathrm{ha}$ of urea at stem extension, as conventional and recommended by the Senegalese agricultural research institute in terms of period of application and dose $\left(69 \mathrm{~kg} \mathrm{~N} \mathrm{ha}^{-1}, 23 \mathrm{~kg} \mathrm{P} \mathrm{ha}^{-1}\right.$ and $23 \mathrm{~kg}$ 
$\mathrm{K} \mathrm{ha}^{-1}$ for sorghum production) i.e., $100 \%$; (iii) $\mathrm{T} 3$, half rate of $\mathrm{T} 2$ applied with the same timing i.e., $50 \%$; (iv) T4: T2 applied with delay, i.e., delay 100\% ; and (v) T5, half rate of T4 applied with the same timing i.e., delay $50 \%$.

Table 2. Fertilization modalities.

\begin{tabular}{ccccc}
\hline & Emergence & Tillering & Stem Extension & Heading \\
\hline T1 (no fertilizer applied) & 0 & 0 & 0 & 0 \\
T2 (recommended practice) & $\mathrm{NPK} *$ & $\mathrm{~N} 1{ }^{* *}$ & $\mathrm{~N} 2{ }^{* * *}$ & \\
T3 & $\frac{1}{2} \mathrm{NPK}$ & $\frac{1}{2} \mathrm{~N} 1$ & $\frac{1}{2} \mathrm{~N} 2$ & $\mathrm{~N}$ + 1 \\
T4 & & $\frac{1}{2}(\mathrm{NPK}+\mathrm{N} 1)$ & $\frac{1}{2} \mathrm{~N} 2$ \\
T5 & & & & \\
\hline
\end{tabular}

${ }^{*}$ NPK (15-15-15): 150kg/ha; ${ }^{* *}$ N1: urea (46\%) 50kg/ha; ${ }^{* * *}$ urea $50 \mathrm{~kg} / \mathrm{ha}$.

Except T2 a research recommendation for sorghum cultivation in Senegal, other modalities were determined by considering possible scenarios of fertilizer application resulting from the weather forecasts and/or rainfall observed at the beginning of the growing season. Modalities T4 and T5 could be practiced in the case that the forecasts are uncertain, but the season starts slowly and seems to be good finally. In this case no fertilizer will be applied at the beginning, but as the season starts again to be rainy, the farmers will apply fertilizers later. Because of logistical reasons, there was no modality testing the situation where the season would become catastrophic after a good beginning, which would lead farmers to not apply urea after doing an initial application of NPK. However, it can be considered that this situation is globally governed by the T1 and T3 modalities.

The four sorghum genotypes (Fadda, Soumalemba, Soumba, and Faourou) were assigned to the subplots. Table 3 showed the characteristics of the four sorghum genotypes used in this study. They differ in terms of phenology (short, medium and long cycle duration), architecture (tall or short), response to inputs (hybrid vs. open pollinated varieties), and usage (grain or dual purpose).

Table 3. Characteristics of sorghum genotypes used.

\begin{tabular}{|c|c|c|c|c|c|c|c|}
\hline Name & Origin & Race & $\begin{array}{c}\text { Cycle } \\
\text { Duration }\end{array}$ & $\begin{array}{c}\text { Photoperiod } \\
\text { Sensitivity }\end{array}$ & Architecture & Use & Yield Potential (ton/ha) \\
\hline Fadda * & Mali & Guinea-hybrid & Medium & Sensitive & Tall & $\begin{array}{c}\text { Dual } \\
\text { purpose }\end{array}$ & 4 \\
\hline Soumalemba & Mali & Guinea-OPV & Long & Sensitive & Tall & Grain & 2 \\
\hline Soumba & Mali & Caudatum-OPV & Medium & $\begin{array}{l}\text { Slightly } \\
\text { sensitive }\end{array}$ & Small & $\begin{array}{c}\text { Dual } \\
\text { purpose }\end{array}$ & 2.8 \\
\hline Faourou & Senegal & Caudatum-OPV & Short & Not sensitive & Small & Grain & 3 \\
\hline
\end{tabular}

* Fadda parental lines are 02-SB-F5DT-12A x Lata, Cycle duration: short: < 100 days, Medium from 100 to 125 days

Long: > 125 days; Architecture: Tall: $>3$ m, Small < 2 m, OPV: Open Pollinated Varieties.

\subsection{Data Collection}

To assess the effect of late fertilizer application on plant growth, aboveground biomass was collected on each subplot at tillering (B1, always before late fertilizer application) and at full flowering (B2, always after late fertilization), on two 4-hills plots randomly selected on the three central rows. Dry biomass was assessed after a controlled drying process (first under a greenhouse and then in an oven at $65^{\circ} \mathrm{C}$ ). These data were measured in all the experiments with the exception of B1 for Nioro du Rip 2016 rainfed (N16-R), due to poor early growing conditions.

At physiological maturity, twelve central hills of each subplot were harvested to assess the grain yield $(\mathrm{Y})$ and vegetative above biomass $(\mathrm{YB})$ after a controlled drying process. Grain yields are based on dry weights without any adjustment (i.e., $0 \%$ moisture). The indexes called gain yield index $\left(\mathrm{G} 1_{\mathrm{ij}}\right.$, $\mathrm{G}_{4 \mathrm{j}}$, and $\mathrm{G}_{5 \mathrm{j}}$ ) were calculated to evaluate the effect of late fertilization treatments (T4; T5) compared to other (T1; T2 and T3):

$$
\mathrm{G1}_{\mathrm{ij}}=\left(\mathrm{Y}_{\mathrm{ij}}-\mathrm{Y}_{1 \mathrm{j}}\right) / \mathrm{Y}_{1 \mathrm{j}}
$$




$$
\begin{aligned}
G 2_{4 j} & =\left(Y_{4 j}-Y_{2 j}\right) / Y_{2 j} \\
G 3_{5 j} & =\left(Y_{5 j}-Y_{3 j}\right) / Y_{3 j}
\end{aligned}
$$

where $Y_{i j}$ grain yield of genotype $j$ under fertilization treatment $i\left(i=T 4\right.$ and $T 5$ ); $Y_{1 j}$ being the yield of genotype $\mathrm{j}$ for T1 (control with no fertilizer application corresponding to farmers' practice); $\mathrm{Y}_{2 \mathrm{j}}$ being the yield of genotype $\mathrm{j}$ for $\mathrm{T} 2$ (recommended practice in terms of fertilizer rate and timing of its application), $\mathrm{Y}_{3 \mathrm{j}}$ being the yield of genotype $\mathrm{j}$ for $\mathrm{T} 3, \mathrm{Y}_{4 \mathrm{j}}$ being its yield for $\mathrm{T} 4$ and $\mathrm{Y}_{5 \mathrm{j}}$ being its yield for T5.

\subsection{Data Analysis}

Statistical analyses were performed using R program, version 3.4.0 [41]. To test the response of the four West-African sorghum genotypes to fertilizer application (NPK and urea) under different environmental conditions, all data for each parameter were pooled over the two years according to the randomized complete block design arranged in a split-plot and combined over locations and years [42]. The data was subjected to analysis of variance (ANOVA). Treatment means were compared using the Least Significant Difference (LSD) at the 5\% level of probability.

Further, indicators to characterize the experimental conditions were defined as follow: (i) the amount of water (rainfalls and irrigations) received from the late application to 25-days after flowering (25-days after flowering correspond to the end of grain filling) (WLAF25), and (ii) the soil N content prior to sowing.

\section{Results}

\subsection{Experimental Conditions}

Figure 1 displays cumulative water, mean air temperatures recorded in the two sites (Nioro du Rip and Sinthiou Malème) over the two years. The temperatures were slightly higher in 2016 than in 2015, and slightly higher in Sinthou Malème than in Nioro du Rip irrespective of the year. The temperature decreased from the date of sowing to the decade 27 where it increased slightly until the decade 30 (corresponding to the end of grain filling stage for Faourou and Soumba and the beginning for Fadda and Soumalemba) before decreasing again. Nioro du Rip irrigated experiment (N15-I) in 2015 was the wettest (1155 mm), followed by Nioro du Rip 2016 Irrigated (N16-I, $1111 \mathrm{~mm})$, Nioro du Rip 2015 rainfed (N15-R, 1045 mm), Nioro du Rip 2016 Rainfed (N16-R, 761 mm), Sinthiou Malème 2015 rainfed (S15-R, $563 \mathrm{~mm}$ ), and last Sinthiou Malème 2016 rainfed (S16-R, $447 \mathrm{~mm}$ ) (Figure 1). The amount of water received from the late application (i.e., stem extension stage) to 25-days after flowering (WLAF25), period critical for plant growth and grain filling, varied according to environment (rainfall distribution) and genotype cycle duration (Table 4).

Table 4. Indicators characterizing the environments.

\begin{tabular}{cccc}
\hline Environments & Range of WLAF25 $\mathbf{( m m )}$ & $\begin{array}{c}\text { Soil N } \mathbf{( k g} / \mathbf{h a} \text { top 0-30 } \\
\mathbf{c m}\end{array}$ & $\begin{array}{c}\text { Environment } \\
\text { Appreciation }\end{array}$ \\
\hline N15-R & $307-488$ & 231 & High N \\
N15-I & $327-600$ & 209 & High N \\
N16-I & $648-726$ & 186 & Low N \\
N16-R & $360-600$ & 235 & High N \\
S15-R & $431^{\text {a }}$ & 167 & Low N \\
S16-R & $181-241$ & 228 & High N \\
\hline
\end{tabular}

WLAF25: Water amount received from the Late Application to 25-days after Flowering; ${ }^{a}$ no differences in WLAF25 for the four genotypes.

Experimental conditions also differed in term of nitrogen content in the $30 \mathrm{~cm}$ top soil, which varied from 167 to $235 \mathrm{~kg} / \mathrm{ha}$, leading us to consider two soil fertility conditions: environments with 
soil $\mathrm{N}$ content lower than $200 \mathrm{~kg} / \mathrm{ha}$ (Low N) and environments with soil $\mathrm{N}$ content higher than 200 $\mathrm{kg} / \mathrm{ha}($ High N) (Table 4).

\section{2. $G^{*} E^{*} M$ Interaction Analysis}

All single factors (Genotype, Environment, Management) showed a significant effect at $P<0.05$, on all variables (Table 5). The interaction of $E^{*} M$ (i.e., Environment $x$ fertilizer Management) and the $G^{*} E$ interaction (i.e., Genotype $x$ Environment) showed significant effect on grain yield and the different measured biomass. The interaction of $G^{*} \mathrm{M}$ exerted significant effect on all biomass measurements only. The triple interaction $G^{*} E^{*} M$ (i.e., Genotype $x$ Environment $x$ fertilizer Management) affected significantly grain yield only (Table 5).

Table 5. Effect of genotype, environment and fertilizer management on yield and biomass.

\begin{tabular}{|c|c|c|c|c|}
\hline \multirow{2}{*}{ Source } & \multirow{2}{*}{$\begin{array}{l}\text { Grain Yield } \\
(\mathrm{kg} / \mathrm{ha})\end{array}$} & \multicolumn{3}{|c|}{ Biomass (kg/ha) } \\
\hline & & B1 & B2 & YB \\
\hline \multicolumn{5}{|c|}{ Genotype (G) } \\
\hline Fadda & $1097 \mathrm{a}$ & $95 \mathrm{~b}$ & $7897 \mathrm{a}$ & $5855 \mathrm{~b}$ \\
\hline Soumalemba & 1038 a & $158 \mathrm{a}$ & 7797 a & $6873 \mathrm{a}$ \\
\hline Soumba & $901 \mathrm{~b}$ & $76 \mathrm{c}$ & $5311 \mathrm{~b}$ & $3347 \mathrm{c}$ \\
\hline Faourou & 1031 a & $91 \mathrm{bc}$ & $3925 \mathrm{c}$ & $2385 \mathrm{~d}$ \\
\hline \multicolumn{5}{|c|}{ Environment (E) } \\
\hline N15-I & $1170 \mathrm{~b}$ & $68 d$ & $6387 \mathrm{~b}$ & $5046 \mathrm{~b}$ \\
\hline N16-I & $837 \mathrm{c}$ & $118 \mathrm{~b}$ & $5893 \mathrm{bc}$ & $4597 \mathrm{bc}$ \\
\hline N15-R & $915 c$ & $96 c$ & $5361 \mathrm{c}$ & $5044 \mathrm{~b}$ \\
\hline N16-R & $604 \mathrm{~d}$ & - & $3728 \mathrm{~d}$ & $2658 \mathrm{~d}$ \\
\hline S15-R & $929 c$ & $15 \mathrm{e}$ & $6315 \mathrm{bc}$ & 4289 c \\
\hline S16-R & $1617 \mathrm{a}$ & $160 \mathrm{a}$ & 9422 a & $6072 \mathrm{a}$ \\
\hline \multicolumn{5}{|c|}{ Fertilizer Management (M) } \\
\hline $\mathrm{T} 1$ & $753 c$ & $79 \mathrm{~b}$ & $5061 \mathrm{~d}$ & $3371 \mathrm{c}$ \\
\hline $\mathrm{T} 2$ & $1297 \mathrm{a}$ & $151 \mathrm{a}$ & 7992 a & 5781 a \\
\hline $\mathrm{T} 3$ & $1085 \mathrm{~b}$ & $136 \mathrm{a}$ & 6069 bc & $4895 \mathrm{~b}$ \\
\hline $\mathrm{T} 4$ & $1102 \mathrm{~b}$ & $89 \mathrm{~b}$ & 6512 b & $5270 \mathrm{ab}$ \\
\hline $\mathrm{T} 5$ & 842 c & $71 \mathrm{~b}$ & $5395 \mathrm{~cd}$ & 3811 c \\
\hline \multicolumn{5}{|c|}{ Significance } \\
\hline$G$ & * & $* * *$ & $* * *$ & $* * *$ \\
\hline $\mathrm{E}$ & $* * *$ & $* * *$ & $* * *$ & $* * *$ \\
\hline $\mathrm{M}$ & $* * *$ & $* * *$ & $* * *$ & $* * *$ \\
\hline $\mathrm{E}^{*} \mathrm{M}$ & $* *$ & $* *$ & * & $* * *$ \\
\hline$G^{*} \mathrm{E}$ & $* * *$ & $* * *$ & $* * *$ & $* * *$ \\
\hline $\mathrm{G}^{*} \mathrm{M}$ & ns & * & * & $* *$ \\
\hline $\mathrm{G}^{*} \mathrm{E}^{*} \mathrm{M}$ & $*$ & ns & ns & ns \\
\hline
\end{tabular}

“_" Data not recorded; Within genotypes, environments and fertilizer management means followed by the same letters are not significantly different at $P<0.05$; B1: Biomass Before Late Application, B2: Biomass after late application at full flowering stage; YB: Vegetative biomass at harvest, N15-I: Nioro du Rip 2015 Irrigated, N15-R: Nioro du Rip 2015 Rainfed, N16-I: Nioro du Rip 2016 Irrigated, N16-R: Nioro du Rip 2016 Rainfed, S15-R: Sinthiou Malème 2015 Rainfed, S16-R: Sinthiou Malème 2016 Rainfed. T1 = no fertilizer; T2 = 150 kg/ha of NPK (15-15-15) at emergence $+50 \mathrm{~kg} / \mathrm{ha}$ of urea $(46 \%)$ at tillering $+50 \mathrm{Kg} / \mathrm{ha}$ of urea at stem extension; $\mathrm{T} 3=75 \mathrm{~kg} / \mathrm{ha}$ of NPK $(15-15-15)$ at emergence $+25 \mathrm{~kg} / \mathrm{ha}$ of urea $(46 \%)$ at tillering $+25 \mathrm{Kg} / \mathrm{ha}$ of urea at stem extension; T4 $=150 \mathrm{~kg} / \mathrm{ha}$ of NPK +50 $\mathrm{kg} / \mathrm{ha}$ of urea at stem extension $+50 \mathrm{~kg} / \mathrm{ha}$ of urea at heading; T5 $=75 \mathrm{~kg} / \mathrm{ha}$ of NPK $(15-15-15)+25 \mathrm{~kg} / \mathrm{ha}$ of urea $(46 \%)$ at stem extension $+25 \mathrm{Kg} / \mathrm{ha}$ of urea at heading. $\mathrm{E}^{*} \mathrm{M}$ : interaction between Environment and fertilizer Management, $\mathrm{G}^{*} \mathrm{E}$ : interaction between Genotypes and Environment; $\mathrm{G}^{*} \mathrm{M}$ : interaction between Genotypes and Management; $\mathrm{G}^{*} \mathrm{E}^{*} \mathrm{M}$ : interaction between Genotypes, Environment and Management; ${ }^{*}$ Significant at the 0.05 probability level; ${ }^{* *}$ Significant at the the 0.01 probability level; ${ }^{* *}$ Significant at the 0.001 probability level; ns Not significant. 


\subsection{Late Fertilization to Boost Stressed Plant}

Figure 3 shows the $\mathrm{E}^{*} \mathrm{M}$ interaction with mean biomass and standard error for each sampling time. Figure 3a showed the plants collected at tillering (B1), before the first application of the late fertilizer application treatments (i.e., stem extension), had less biomass (mean and errorbar) in T4 than $\mathrm{T} 2$, and in $\mathrm{T} 5$ compared to $\mathrm{T} 3$ for all environments. This proves that sorghum plants, no matter the genotypes did experience a stress if they did not receive any fertilizers before stem elongation (treatments $\mathrm{T} 4$ and T5). In S15-R, the B1 biomass were very low for all treatments. The maximum B1 biomass for T4 was obtained in N16-I experiment (135 kg/ha) while the maximum B1 biomass for T5 (113 kg/ha) was obtained in S16-R (Figure 3a). According to B2 biomass data (Figure 3b), biomass collected after late fertilizer application (i.e., full flowering), plants in T4 remained stressed compared to T2 in three experiments (N15-I, N16-R and S16-R) out of six. In the other environments, all biomass measurements were similar for T4 and T2 treatments. However, Figure 3b shows that, at that same time of measurements, dry matter produced under T5 was lower than the T3 one, only in the N16-R experiment. Biomass at harvest (YB) was also affected by environment and fertilization $\left(E^{*} M\right)$ interactions (Figure 3c). Aboveground biomass decreased at harvest compared to the biomass measured after late application (B2 at full flowering stage) due to the senescence. Plant produced less biomass under T4 compared to T2 only in N15-I; under T5 compared to T3 in N15-R, N16-I, and N16-R (Figure 3c).
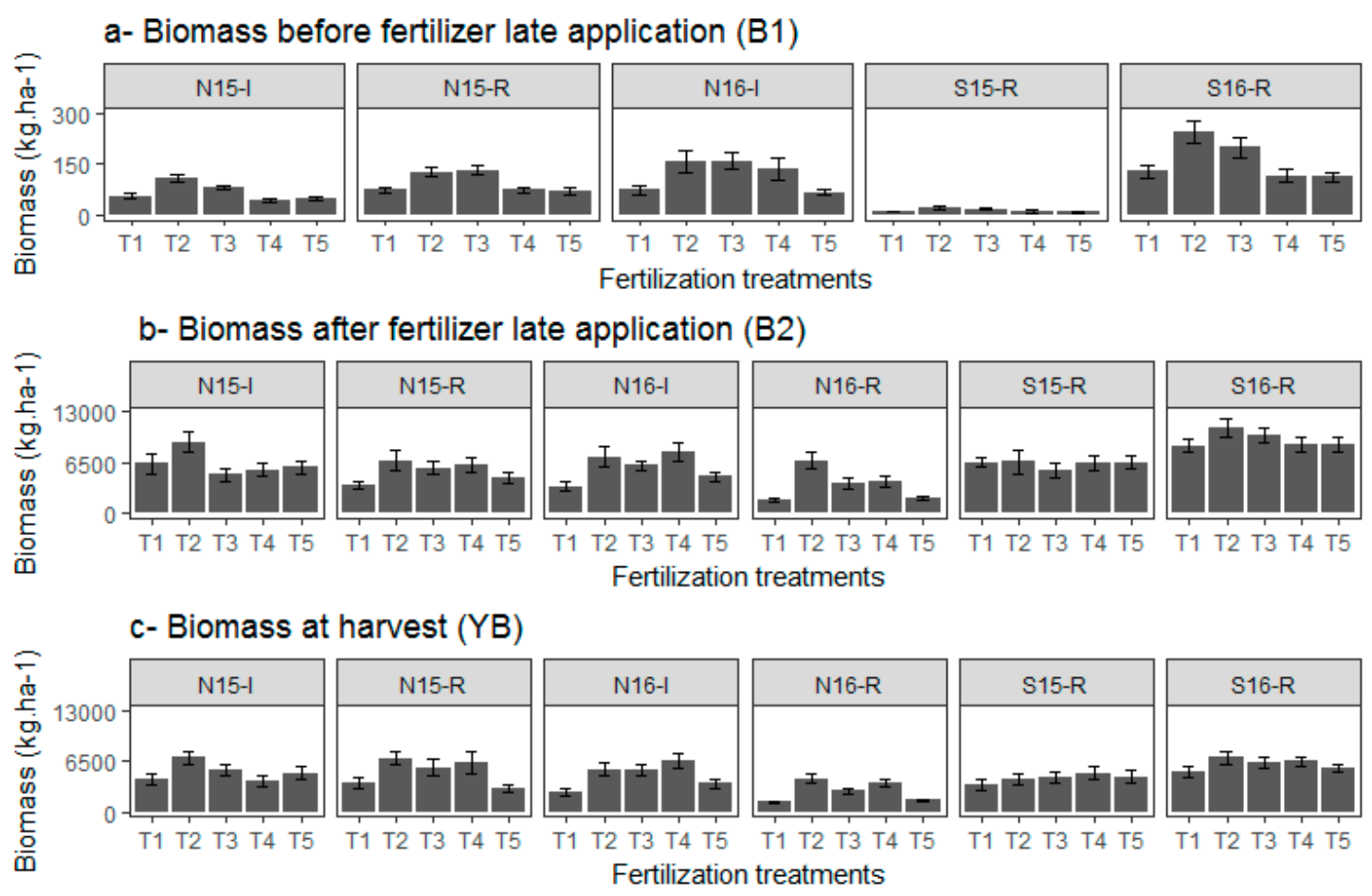

Figure 3. Biomass dynamic (means and error bars (a) before and (b) after late fertilizer application and (c) at harvest) according to fertilizer modalities in different environments; N15-I: Nioro du Rip 2015 Irrigated with 1155 mm of water, N15-R: Nioro du Rip 2015 Rainfed with 1045 mm of water, N16-I: Nioro du Rip 2016 Irrigated with 1111 mm of water, N16-R: Nioro du Rip 2016 Rainfed with 761 mm of water, S15-R: Sinthiou Malème 2015 Rainfed with $563 \mathrm{~mm}$ of water, S16-R: Sinthiou Malème 2016 Rainfed with $447 \mathrm{~mm}$ of water. T1 = no fertilizer; T2 = $150 \mathrm{~kg} / \mathrm{ha}$ of NPK (15-15-15) at emergence $+50 \mathrm{~kg} / \mathrm{ha}$ of urea $(46 \%)$ at tillering $+50 \mathrm{Kg} / \mathrm{ha}$ of urea at stem extension; T3 $=75 \mathrm{~kg} / \mathrm{ha}$ of NPK at emergence $+25 \mathrm{~kg} / \mathrm{h}$ of urea at tillering $+25 \mathrm{Kg} / \mathrm{ha}$ of urea at stem extension; T4 $=150 \mathrm{~kg} / \mathrm{ha}$ of NPK + $50 \mathrm{~kg} / \mathrm{ha}$ of urea at stem extension $+50 \mathrm{~kg} / \mathrm{ha}$ of urea at heading; T5 $=75 \mathrm{~kg} / \mathrm{ha}$ of NPK $+25 \mathrm{~kg} / \mathrm{ha}$ of urea at stem extension $+25 \mathrm{Kg} / \mathrm{ha}$ of urea at heading. 
In addition, $G^{*} E$ interactions affected biomass yield (YB). Maximum YB was obtained for Faourou (3427 kg/ha), Soumalemba (9178 kg/ha) and Soumba (4961 kg/ha) in S16-R experiment while Fadda gave maximum biomass (7485 kg/ha) in N15-R. Minimum YB was recorded in N16-R experiment for Fadda (3253 kg/ha), Soumalemba (3542 kg/ha) and Soumba (2057 kg/ha) whereas for Faourou $(1589 \mathrm{~kg} / \mathrm{ha})$, it was lower in S15-R experiment. YB was also affected by $\mathrm{G}^{*} \mathrm{M}$ interactions (Figure 4). The maximum biomass was produced by Soumalemba under $\mathrm{T} 2$ and the minimum by Faourou under T1. Fadda and Soumalemba performed better under T4 compared to other genotypes. While Faourou was consistently the lowest performing genotype followed by Soumba irrespective of the fertilization treatment, Soumalemba reacted better under T1, T2, T3, and T5. The main interaction is between Fadda and Soumbalemba with respect to their response to T4, where Fadda responded better than Soumbalemba (Figure 4).

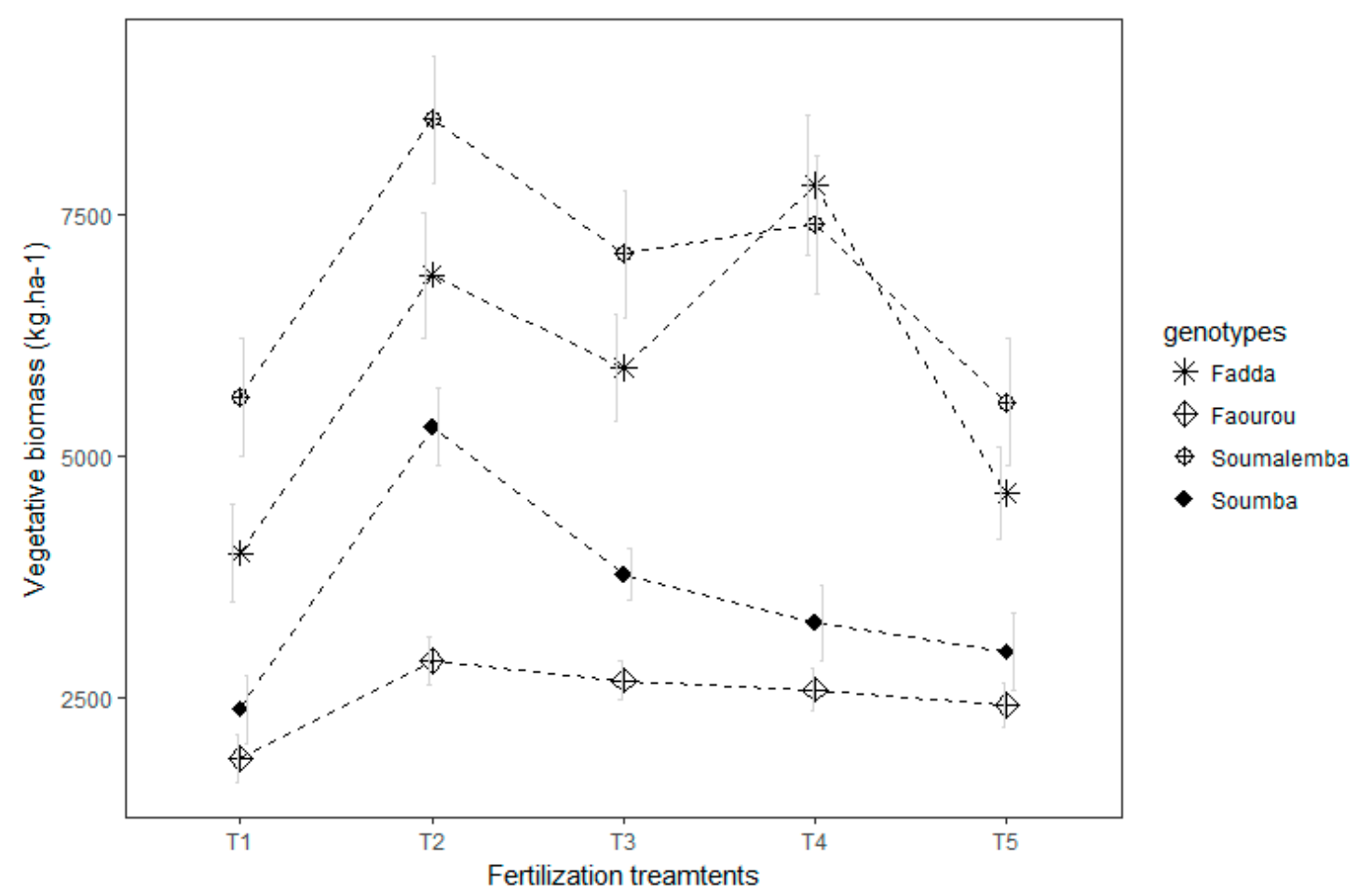

Figure 4. Mean biomass with error bars at harvest according to genotypes and fertilizer modalities; $\mathrm{T} 1=$ no fertilizer; T2 $=150 \mathrm{~kg} / \mathrm{ha}$ of NPK (15-15-15) at emergence $+50 \mathrm{~kg} / \mathrm{ha}$ of urea $(46 \%)$ at tillering $+50 \mathrm{Kg} / \mathrm{ha}$ of urea at stem extension; T3 $=75 \mathrm{~kg} / \mathrm{ha}$ of NPK at emergence $+25 \mathrm{~kg} / \mathrm{ha}$ of urea at tillering $+25 \mathrm{Kg} / \mathrm{ha}$ of urea at stem extension; T4 $=150 \mathrm{~kg} / \mathrm{ha}$ of NPK $+50 \mathrm{~kg} / \mathrm{ha}$ of urea at stem extension +50 $\mathrm{kg} / \mathrm{ha}$ of urea at heading; T5 $=75 \mathrm{~kg} / \mathrm{ha}$ of NPK $+25 \mathrm{~kg} / \mathrm{ha}$ of urea at stem extension $+25 \mathrm{Kg} / \mathrm{ha}$ of urea at heading.

\subsection{Late fertilization Benefit on Grain Yield}

The lowest grain yields (significantly different from T2, T3 and T4) were observed for T5 (late applications of amounts similar to T3) and T1 (no fertilizer application) (Figure 5). Also, we found that late fertilization treatment T4, and T5 (except in N15-R and N16-R) gave better grain yield than T1 (farmers' strategies to face rainfall uncertainties) regardless of the environments (Figure 5). In addition, S16-R and N16-R were the highest and lowest (respectively) performing environments irrespective of the fertilization treatments. However, we could also notice that grain yield response to fertilizer treatments differed according to environments ( $\mathrm{E}^{*} \mathrm{M}$ interaction, Figure 5). N16-I appears to have a better response to late full fertilizer rate application than other sites (Figure 5). T5 performed better than T4 in the wettest condition (N15-I, Figure 5). And, T4's grain yield is higher than T2 ones in the 
environments with low potential i.e., once T2s' grain yields are below $888 \mathrm{~kg} / \mathrm{ha}$, the average sorghum grain yield in Senegal from 2012 to 2016 (N16-I and N16-R, Figure 5).

In addition to the $E^{*} M$ and $G^{*} E$ interactions, the ANOVA showed a significant $G^{*} E^{*} M$ interaction. The grain yield ranged from 100 to $2578 \mathrm{~kg} / \mathrm{ha}$ with an average value of $1017 \mathrm{~kg} / \mathrm{ha}$. The best grain yield response was obtained with $\mathrm{T} 2$ for Soumba in almost all environments whereas for Soumalemba, it was obtained with T2 in N16-R and S16-R, T4 in N15-R, N16-I and S15-R and T5 in N15-I. Faourou gave the best yield with T5 in S16-R, with T4 in N16-R, S15-R, and S16-R, with T3 in N16-I and with T2 in N15-I and N15-R whereas the best yield was obtained for Fadda with T3 in N16-R and S16-R; with T2 in N15-I, N15-R and S15-R, and with T5 in N16-I (Figure S1).

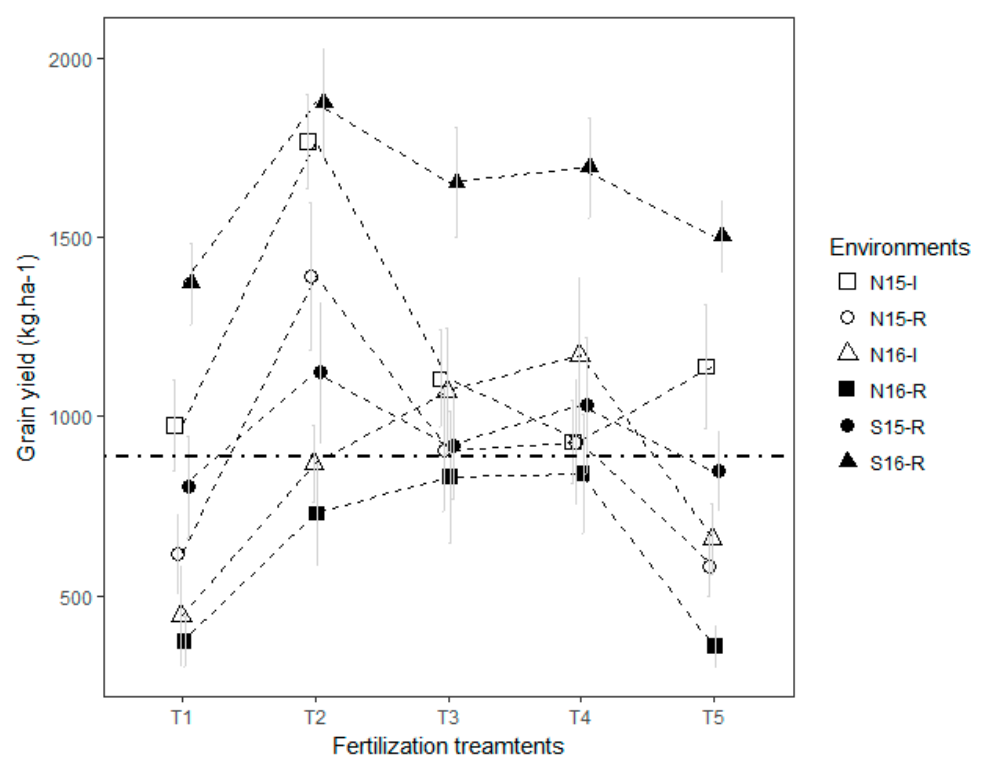

Figure 5. Mean grain yield with error bars according to environments and fertilizer modalities; N15-I: Nioro 2015 Irrigated with 1155 mm of water, N15-R: Nioro du Rip 2015 Rainfed with 1045 mm of water, N16-I : Nioro du Rip 2016 Irrigated with 1111 mm of water, N16-R: Nioro du Rip 2016 Rainfed with 761 mm of water, S15-R: Sinthiou Malème 2015 Rainfed with 563 mm of water, S16-R: Sinthiou Malème 2016 Rainfed with $447 \mathrm{~mm}$ of water. T1 = no fertilizer; T2 $=150 \mathrm{~kg} / \mathrm{ha}$ of NPK (15-15-15) at emergence $+50 \mathrm{~kg} / \mathrm{ha}$ of urea $(46 \%)$ at tillering $+50 \mathrm{Kg} / \mathrm{ha}$ of urea at stem extension; T3 $=75 \mathrm{~kg} / \mathrm{ha}$ of NPK at emergence $+25 \mathrm{~kg} / \mathrm{ha}$ of urea $(46 \%)$ at tillering $+25 \mathrm{Kg} / \mathrm{ha}$ of urea at stem extension; T4 $=150 \mathrm{~kg} / \mathrm{ha}$ of $\mathrm{NPK}+50 \mathrm{~kg} / \mathrm{ha}$ of urea at stem extension $+50 \mathrm{~kg} / \mathrm{ha}$ of urea at heading; T5 = $75 \mathrm{~kg} / \mathrm{ha}$ of NPK (15-15-15) $+25 \mathrm{~kg} / \mathrm{ha}$ of urea $(46 \%)$ at stem extension $+25 \mathrm{Kg} / \mathrm{ha}$ of urea at heading. The dashed line represents the threshold's grain yield for low potential sites.

To further explain these results on grain yield and their sources of variation due to genotype, environments (WLAF25 and site potential, i.e., total $\mathrm{N}$ level), and fertilizer applications, Figure 6 shows more specifically yield gain due to late fertilizer treatments for the different genotypes. These results confirm the gain $\left(\mathrm{G}_{1}\right)$ in general with the late applications compared to T1 (farmers' practice) regardless of the environments (Figure $6 \mathrm{a}, \mathrm{b}$ ). We observe a clear response of Soumbalemba in high $\mathrm{N}$ environments with dry end of the season conditions, and of Fadda in low $\mathrm{N}$ environments with a wet end of the season conditions (especially with T5, a late application with half the dose). When comparing $\mathrm{T} 4$ with the research recommended practices $\mathrm{T} 2$ (effect of delay fertilization, $\mathrm{G}_{2}$, Figure $6 \mathrm{c}$ ), there was no advantage of delaying fertilization for Soumalemba and Soumba on high $\mathrm{N}$ content soils irrespective of the amount of WLAF25, while for Faourou there was an advantage when WLAF25 was above $600 \mathrm{~mm}$ independently of N content in soils. Concerning Fadda, it had a better grain yield with T4 compared to T2 only on high N content soils with WLAF25 less than $400 \mathrm{~mm}$ (Figure 6c). Finally, while comparing the delay effect for half dose of the recommendation (T5 vs. T3, G3, Figure 6d) there was no advantage for early maturing genotypes (Faourou and Soumba), except for Faourou 
when it received little water (WLAF25 $<400 \mathrm{~mm}$ ) after late application. Fadda responded better to delayed fertilization when WLAF25 was above $600 \mathrm{~mm}$ irrespective of the soil $\mathrm{N}$ content. Faourou and Soumalemba gave better grain yield under T5 compared to T3 if WLAF25 was less than $400 \mathrm{~mm}$ on high N content soils and if WLAF25 ranged from 400 to $500 \mathrm{~mm}$ on low N content soils (Figure 6d).
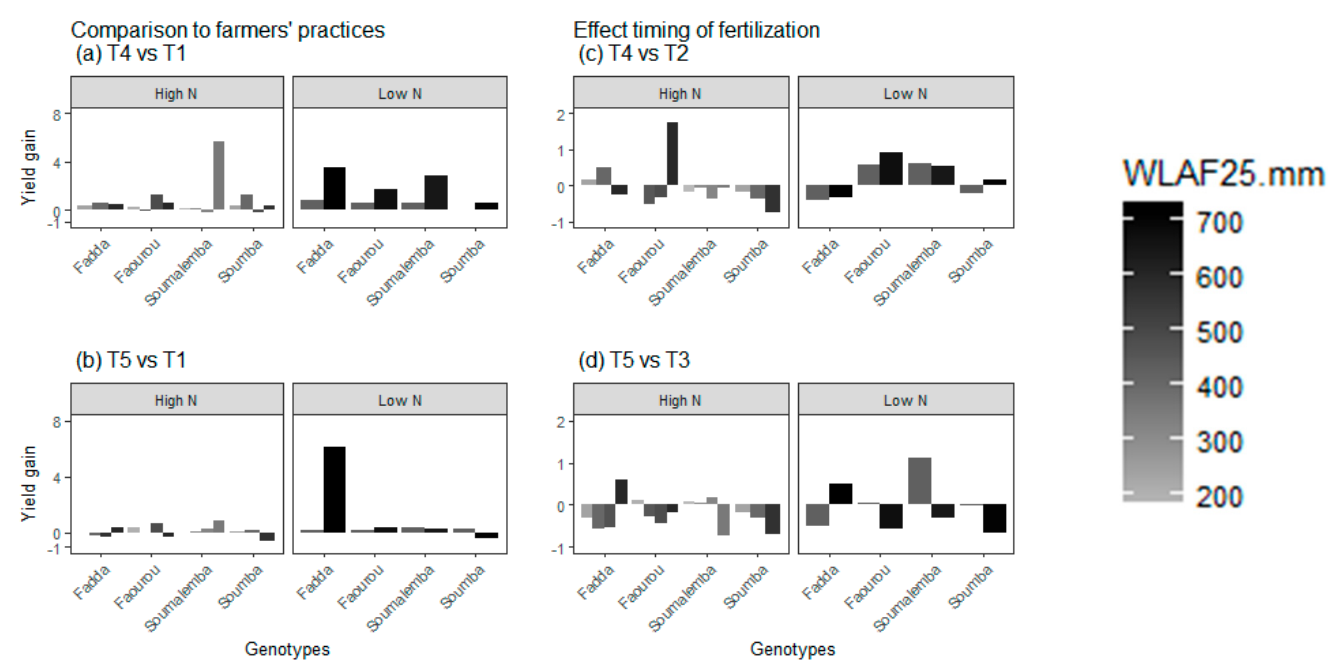

Figure 6. Gain yield with late fertilization treatments: comparison to farmers' practices i.e., $\mathrm{G}_{\mathrm{ij}}(\mathbf{a})-\mathrm{T} 4$ vs. T1 and (b) T5 vs. T1, effect timing of fertilization i.e., G2 4 j, (c)T4 vs. T2, and G3 $3_{5 j}$ (d) T5 vs. T3); WLAF25: Water recorded from first Late fertilizer Application to 25 days after Flowering in millimeter.

\section{Discussion}

In this study, the effect of different doses of fertilizer and its split application (conventional and late-season application) was investigated in different conditions for four contrasting sorghum genotypes (hybrid and Open Pollinated Varieties) during two consecutive years at Nioro du Rip and Sinthiou Malème in Senegal. Results showed that $G^{*} E$ and $E^{*} M$ interactions had a significant effect on aboveground biomass and grain yield. This supports the importance of targeting the genotypes according to environments and to tailor the fertilization (timing and dose) according to environments. These results are in agreement with findings reported by other authors [21].

\subsection{Importance of Late Fertilization for Vegetative Growth, Especially for Hybrids}

Initially stressed under late fertilization treatments (T4 and T5), plants recovered growth rate in most environments after late fertilizer application (E.K.K.G. N15-R, N16-I, S15-R, Figure 3a,b) indicating that growth delay associated with nitrogen stress in the beginning of vegetative phase can be recovered. These results also suggest that the late $\mathrm{N}$ fertilizer apparently stimulated the vegetative growth. Nitrogen affects plant growth through cell division and cell enlargement [43], which consequently may increase plant biomass, especially when stem elongation starts. The sorghum plant nutrition dynamic depends on crop cycle however, early growth stages are important. For instance, at the half-bloom stage of a sorghum of about 100 days cycle duration, nearly $60 \%$ of the phosphorus, $70 \%$ of the nitrogen, and $80 \%$ of the potassium have already been taken up according to Vanderlip [44]. In this study, the late application occurred in beginning of stem elongation so plants could still uptake the maximum of nutrients.

Regarding sorghum genotype responses, this study showed the importance of considering genotypes in the analysis of conditions to take advantage of late fertilization. Indeed, both short and long cycle genotypes have responded to late fertilization, but long cycle duration genotypes benefited better from late fertilization compared to short cycle duration genotypes (Figures 4 and 6). Our results are in line with Kante et al. [45] who reported variable grain yields on sorghum in Mali according to the type of genetic material (tall, short hybrids and landrace) and environmental conditions interactions. 
Further, the hybrid Fadda did not perform better than other varieties for grain yield considering the six environments irrespective of fertilization modalities but did for the biomass production. Also, even if in this study, Fadda did not always give the best grain yield, it remained a high-performance dual-purpose variety in Senegal as reported by Ndiaye et al. [46] and Ndiaye, [47] where the hybrids Fadda and Nielini were identified as the best performing varieties for grain yield and biomass yield in eleven environments during 4 years experiments. Our study added to these results, that Fadda, in term of biomass production, did respond better to late fertilizer applications, than other genotypes (Figure 4).

\subsection{Importance of Late Fertilization for Grain Yield, Especially in Low Potential Sites}

Strategies of delaying the basal application affected grain yields in sorghum production, when compared to the recommendation (dose and timing of application). Both an increase (up to 175\%) and decrease (up to $75 \%$ ) of grain yields were recorded (Figure 6c). This finding revealed the importance of adequate basal application (choice of time and dose) according to the context. The timing of the basal fertilizer is critical for farmers as any fertilizer they apply is typically after the first weeding (3-5 weeks after sowing, delayed application) or at sowing/emergence according to the recommended practice. Figure 6 revealed that farmers can benefit from late basal application depending on the genotypes, fertilizer rate, and environments. The basal application should meet both plant requirement of nutrients and suitable soil moisture conditions to reduce nutrient leaching and to increase fertilizer use efficiency. Delaying basal application during the period of low nutrient requirements and reducing the amount of fertilizer supplied when the plant is small can be effective in increasing fertilizer use efficiency [48]. This is partially confirmed in our study as both full (T4) and half (T5) rates applied late in-season showed gain yield in low potential sites (Figure 5). Grain yield with late application was variable, but results showed grain yield with $\mathrm{T} 4$ (100\% of fertilizer applied late in-season) was superior to T2 $(100 \%$ of fertilizer applied at conventional time, earlier in the season) when there was a low potential of the site for T2 (Figure 5), common situation in low input systems of the Sudano-Sahelian zone. Our results agree with the literature that reported that increase in grain yield due to late fertilizer application varies according to years and locations [49]. The findings that late fertilizer application treatments gave best yield in some environments (irrigation conditions, various total rainfall recorded and soils with different potential) have been previously reported on sorghum in Indian arid areas [28], on durum wheat in temperate areas of North West Italian plain [29] and on rice in Philippian lowland area [32]. Similarly, Sanz Rozas et al. [50] found that $\mathrm{N}$ fertilizer applied at vegetative 6 leaves stage increased grain yields about 3 to $22 \%$ when compared with $\mathrm{N}$ application at planting, mainly in the lower $\mathrm{N}$ rates (70 and $140 \mathrm{~kg} / \mathrm{ha}$ vs. $210 \mathrm{~kg} / \mathrm{ha}$ ). Sitthaphanit et al. [48] reported that postponing the basal application to 7-15 days after emergence increased the maize grain yield about $30 \%$ to $37 \%$ when compared to the pre-planting application on sandy soils under high rainfall regimes. Our study confirms these findings.

In addition, the fertilizer treatment $\mathrm{T} 5,50 \%$ of the recommended dose of fertilizer applied late in-season did better than $\mathrm{T} 4$ (100\% of the recommended dose of fertilizer applied late in-season) under wettest condition i.e., N15-I (Figure 5) probably because excessive dose of nitrogen under T4 leached on sandy soil. This result indicates that in a wetter condition, the reduced amounts of fertilizer applied late in-season would be the most beneficial. This result is consistent with Mon et al. [22] who demonstrated interactive effects of nitrogen fertilization and irrigation on durum wheat grain yield where $\mathrm{N}$ fertilizer (applied at stem elongation and pre-boot stages) improved grain yield response to irrigation on sandy loam soil. Furthermore, in Sinthiou Malème 2015, where the rainy season had a slow start (Figure 1b), late fertilization treatments showed better grain yield (Figure 5) confirming our first hypothesis that late fertilization would be beneficial under rainfed conditions with a well rainfall distribution after a slow beginning of the rainy season.

Lastly, variability in our experimental conditions influenced our results in addition to fertilizer and water interactive effect studied and made some inferences difficult to draw. For instance, we 
noticed that the least rainy environment (S16-R) had the best grain yield and the lowest yields were observed in environment with sufficient rainfall (N16-R, $761 \mathrm{~mm}$ Figure 5). This could be explained by the positive effects of the more important percentage of fine soil components $(8.3 \%$ of silt and $8.8 \%$ of clay, Table 1) inducing a better soil moisture conservation. However, while making a covariance analysis (Table S1) to dissociate this effect of soil texture (silt percent as co-variable) from other factors in the environments tested, the probabilities of significance at $5 \%$ did not change for all variables, and hence we did not consider soil texture as a covariate in our analysis. It is important to note this result as it might contribute to the explanation of grain yield response to late fertilizer application in low potential sites.

\section{Conclusions}

This study confirmed that fertilizer management for sorghum production in the Sudano-Sahelian zone should combine fertilization rate and timing of the application according to genotype cycle, previous soil $\mathrm{N}$ content and rainfall distribution in order to optimize grain and biomass yield. Fertilizers rate and timing of application had a significant effect on plant growth (biomass dynamic). Late application enables the plant biomass, initially stressed, to get back to the same level as if the application was done early in the season. This indicates that postponing basal application till stem elongation could still be of beneficial to plants. Also, this study showed that Fadda, a hybrid, responded differently to fertilization than the other varieties for biomass production, and benefited better to late application during the vegetative phase.

Reduced fertilizer rate applied late-in season (T5) was more beneficial than the full rate applied late-in season (T4) for grain yield under wettest condition, suggesting not to apply too much fertilizers in a wet condition. Late fertilizer application treatment (T4) gave higher grain yield than the recommended practice (T2) in the environment with low yield potential (grain yield with T2 $<888$ $\mathrm{kg} / \mathrm{ha}$, national average from 2012 to 2016 in Senegal). It appears that all genotype responds better to late application if they received a lot of water after the application $(\geq 400 \mathrm{~mm})$. However, long cycle varieties (Soumalemba) respond better on soil with a low $\mathrm{N}$ content, whereas, hybrids (Fadda) respond better to late fertilization (low fertilizer amount) irrespective of the soil types.

Results from the present work are useful to design fertilizer application strategies in semi-arid or arid zones like Sahel characterized by rainfall uncertainty and nutrients deficiency in soil. However, to make fertilization recommendations to farmers based on weather forecasts, it will also be important to evaluate a dynamic crop simulation model to reproduce these main results, and, hence, explore several fertilization strategies for sorghum in semi-arid or arid zones.

Supplementary Materials: The following are available online at http://www.mdpi.com/2073-4395/9/11/697/s1, Figure S1. Grain yield for the 4 genotypes under the 6 environments; Table S1. Analysis of variance

Author Contributions: Conceptualization, K.K.G., B.M., A.G. and M.A.; methodology, K.K.G., B.M., A.G. and M.A.; software, K.K.G.; validation, B.M., A.G. and M.A.; formal analysis, K.K.G., B.M., M.N., E.K.G. and M.A.; investigation, K.K.G., B.M., M.N. and E.K.G.; resources, K.K.G., B.M., A.G., and M.A.; data curation, K.G., B.M. and M.A.; writing—original draft preparation, K.K.G.; writing-review and editing, B.M., M.A. and A.G.; visualization, B.M. and M.A.; supervision, B.M., A.G. and M.A.; project administration, B.M. and M.A.; funding acquisition, B.M., M.A.

Funding: This work constitutes part of doctoral research studies funded by DAAD the German exchange service program. The research was conducted with the financial support of the West Africa Agricultural Productivity Program for Senegal (WAAPP-Senegal) and benefit of the facilities of the Centre d'Etude Régional pour l'Amélioration de l'Adaptation à la Sécheresse (CERAAS).

Acknowledgments: The authors thank Mbaye Sarr Diop, Massiré Badji, Bounama Mbengue and Thierno Ndiaye for their invaluable help and cooperation in the laboratory and field work during their master training period. They also thank CGIAR Research Program on Grain Legumes and Dryland Cereals (CRP-GLDC) which funded some research stays of the first author and paid the Article Processing Charges.

Conflicts of Interest: The authors declare no conflict of interest. The funders had no role in the design of the study; in the collection, analyses, or interpretation of data; in the writing of the manuscript, or in the decision to publish the results. 


\section{References}

1. Gueye, T.; Sine, B.; Cisse, N.; Diatta, C.; Ndiaye, S. Characterization of Phenotypic Diversity of Sorghum Collection for Developing Breeding Material. Int. J. Sci. 2016, 5, 38-48. [CrossRef]

2. Kulkarni, D.P.; Almodares, A.; Somani, R.B. Sweet sorghum-Supplementary sugar crop in Iran. Annu. Plant. Physiol. 1995, 9, 90-94.

3. Legwaila, G.M.; Balole, T.V.; Karikari, S.K. Review of sweet sorghum: A potential cash and forage crop in Botswana. J. Agric. 2003, 12, 5-14. [CrossRef]

4. Bantilan, M.C.S.; Deb, U.K.; Gowda, C.L.L.; Reddy, B.V.S.; Obilana, A.B.; Evenson, R. Sorghum Genetic Enhancement: Research Process, Dissemination and Impacts; International Crops Research Institute for the Semi-Arid Tropics: Andhra Pradesh, India, 2004.

5. Geremew, G.; Adugna Asfaw, T.; Taye, T.; Tesfaye, B.; Ketema, B.; Michael, H.S. Development of sorghum varieties and hybrids for dryland areas of Ethiopia. Uganda J. Agric. Sci. 2004, 9, 594-605.

6. Rattunde, H.F.W.; Weltzien, E.; Diallo, B.; Diallo, A.G.; Sidibe, M.; Touré, A.O.; Rathore, A.; Das, R.R.; Leiser, W.L.; Touré, A. Yield of Photoperiod-sensitive Sorghum Hybrids Based on Guinea-race Germplasm under Farmers' Field Conditions in Mali. Crop. Sci. 2013, 53, 2454-2461. [CrossRef]

7. Akata, E.A.; Diatta, C.; Faye, J.M.; Diop, A.; Maina, F.; Sine, B.; Tchala, W.; Ndoye, I.; Morris, G.P.; Cisse, N. Combining ability and heterotic pattern in West African sorghum landraces. Afr. Crop. Sci. J. 2017, 25, 491-508. [CrossRef]

8. Cassman, K.K.G. Ecological intensification of cereal production systems: Yield potential, soil quality, and precision agriculture. Proc. Natl. Acad. Sci. USA 1999, 96, 5952-5959. [CrossRef]

9. Cassman, K.K.G. Ecological Intensification of Agriculture and Implications for Improved Water and Nutrient Management. In International Symposium on Fertigation: Optimizing the Utilization of Water and Nutrients; Imas, P., Price, R., Eds.; IPI-NATESC-CAU-CAAS: Beijing, China, 2005; pp. 23-34.

10. Wylie, P. Managing Sorghum for High Yields; Cribb, M., Ed.; Grain Research and Development Corporation (GRDC): Kingston, Jamaic, 2008.

11. Hansen, J.W. Realizing the potential benefits of climate prediction to agriculture: Issues, approaches, challenges. Agric. Syst. 2002, 74, 309-330. [CrossRef]

12. Hulme, M.; Doherty, R.; Ngara, T.; New, M.; Lister, D. African climate change: 1900-2100. Clim. Res. 2001, 17, 145-168. [CrossRef]

13. Ingram, K.T.; Roncoli, M.C.; Kirshen, P.H. Opportunities and constraints for farmers of west Africa to use seasonal precipitation forecasts with Burkina Faso as a case study. Agric. Syst. 2002, 74, 331-349. [CrossRef]

14. Defrance, D.; Ramstein, G.; Charbit, S.; Vrac, M.; Famien, A.M.; Sultan, B.; Swingedouw, D.; Dumas, C.; Gemenne, F.; Alvarez-Solas, J.; et al. Consequences of rapid ice-sheet melting on the Sahelian population vulnerability. Proc. Natl. Acad. Sci. USA 2017, 114, 6533-6538. [CrossRef] [PubMed]

15. Casenave, A.; Valentin, C. Les États de Surface de la Zone Sahélienne : Influence Sur L'infiltration; Institut Français de Recherche Scientifique Pour le Développement en Coopération, ORSTOM, Ministère de la Recherche et de la Technologie: Paris, France, 1989.

16. IPCC. Summary for policymakers. Climate change 2007: Impacts, Adaptations and Vulnerability. In Contribution of Working Group II to the Fourth Assessment of the Intergovernmental Panel on Climate Change; Parry, M.L., Canziani, O.F., Palutikof, J.P., van der Linden, P.J., Hanson, C.E., Eds.; Cambridge University Press: Cambridge, UK, 2007.

17. IPCC. Climate Change 2014: Synthesis Report. In Contribution of Working Groups I, II and III to the Fifth Assessment Report of the Intergovernmental Panel on Climate Change, Core Writing Team; Pachauri, R.K., Meyer, L.A., Eds.; IPCC: Geneva, Switzerland, 2014.

18. Schmidhuber, J.; Tubiello, F.N. Global food security under climate change. Proc. Natl. Acad. Sci. USA 2007, 104, 19703-19708. [CrossRef] [PubMed]

19. Amadou, M.; Gandah, M.; Bielders, C.L.; van Duivenbooden, N. Optimizing soil water use in Niger: Research, development, and perspectives. In Efficient Soil Water Use: The Key to Sustainable Crop Production in Dry Areas of West Asia, and North and Sub-Saharan Africa. Niamey, Niger 26-30 April 1998 and Oman, Jordan 9-13 May 1998; van Duivenbooden, N., Pala, M., Studer, C., Bielders, C.L., Eds.; ICARDA and ICRISAT: Aleppo, Syria, 1999; pp. 143-164. 
20. Gheysari, M.; Mirlatifi, M.S.; Bannayan, M.; Homaee, M.; Hoogenboom, G. Interaction of water and nitrogen on maize grown for silage. Agric. Water Manag. 2009, 96, 809-821. [CrossRef]

21. Kiani, M.; Gheysari, M.; Mostafazadeh-Fard, B.; Majidi, M.M.; Karchani, K.; Hoogenboom, G. Effect of the interaction of water and nitrogen on sunflower under drip irrigation in an arid region. Agric. Water Manag. 2016, 171, 162-172. [CrossRef]

22. Mon, J.; Bronson, K.F.; Hunsaker, D.J.; Thorp, K.R.; White, J.W.; French, A.N. Interactive effects of nitrogen fertilization and irrigation on grain yield, canopy temperature, and nitrogen use efficiency in overhead sprinkler-irrigated durum wheat. Field Crop. Res. 2016, 191, 54-65. [CrossRef]

23. Sultan, B.; Barbier, B.; Fortilus, J.; Mbaye, S.M.; Leclerc, G. Estimating the potential economic value of seasonal forecasts in West Africa: A long-term Ex-Ante assessment in Senegal. Am. Meteorol. Soc. 2010, 2, 69-87. [CrossRef]

24. Roudier, P.; Sultan, B.; Quirion, P.; Baron, C.; Alhassane, A.; Traoré, S.B.; Muller, B. An ex-ante evaluation of the use of seasonal climate forecasts for millet growers in SW Niger. Int. J. Climatol. 2011, 32, 759-771. [CrossRef]

25. Sultan, B.; Gaetani, M. Agriculture in West Africa in the Twenty-first Century: Climate change and impacts scenarios, and potential for adaptation. Front. Plant Sci. 2016, 7, 1-20. [CrossRef]

26. Abad, A.; Lloveras, J.; Michelena, A. Nitrogen fertilization and foliar urea effects on durum wheat yield and quality and on residual soil nitrate in irrigated Mediterranean conditions yield and quality and on residual soil nitrate in. Field Crop. Res. 2004, 87, 257-269. [CrossRef]

27. Velasco, J.L.; Rozas, H.S.; Echeverria, E.; Barbieri, A.P. Optimizing fertilizer nitrogen use efficiency by intensively managed spring wheat in humid regions: Effect of split application. Can. J. Plant. Sci. 2012, 92, 847-856. [CrossRef]

28. Amiri, M.; Mojaddam, M.; Shokouhfar, A.; Bakhtiarinejad, N. The effect of different levels and time of nitrogen application on grain yield, some physiological traits and nitrogen use effiency in grain sorghum. Indian J. Fundam. Appl. Life Sci. 2014, 4, 223-227.

29. Blandino, M.; Vaccino, P.; Reyneri, A. Late-season nitrogen increases improver common and durum wheat quality. Agron. J. 2015, 107, 680-690. [CrossRef]

30. Xue, C.; Erley, S.A.G.; Rossmann, A.; Schuster, R.; Koehler, P.; Mühling, K.-H. Split nitrogen application improves wheat baking quality by influencing protein composition rather than concentration. Front. Plant Sci. 2016, 7, 1-11. [CrossRef]

31. Wuest, S.B.; Cassman, K.K.G. Fertilizer-Nitrogen use efficiency of irrigated wheat: I. Uptake efficiency of preplant versus late-season application. Agron. J. 1992, 84, 682-688. [CrossRef]

32. Perez, C.M.; Juliano, B.; Liboon, S.P.; Alcantara, J.M.; Cassman, K.K.G. Effects of late nitrogen fertilizer application on head rice yield, protein content, and grain quality of rice. Cereal Chem. 1996, 73, 556-560.

33. Bodson, B.; Vancutsem, F.; Destain, J.; Herman, J.; Monfort, B.; Couvreur, L. Evolution du fractionnement de la fumure azotée. In Livre Blanc Céréales; CRA, Ed.; FUSAGx: Gembloux, Belgique, 2003; pp. 1-8.

34. Spiertz, J.H.J.; Ellen, J. Effects of nitrogen on crop development and grain growth of winter wheat in relation to assimilation and utilization of assimilates and nutrients. Neth. J. Agric. Sci. 1978, 26, $210-231$.

35. Hucklesby, D.P.; Brown, C.M.; Howell, S.E.; Hageman, R.H. Late Spring applications of nitrogen for efficient utilization and enhanced production of grain and grain protein of wheat1. Agron. J. 1971, 63, $274-276$. [CrossRef]

36. Pushman, F.M.; Bingham, J. The effects of a granular nitrogen fertilizer and a foliar spray of urea on the yield and bread-making quality of ten winter wheats. J. Agric. Sci. 1976, 87, 281-292. [CrossRef]

37. Strong, W.M. Effect of late application of nitrogen on the yield and protein content of wheat. Aust. J. Exp. Agric. 1982, 22, 54-61. [CrossRef]

38. Rötter, R.; Van Keulen, H. Variations in yield response to fertilizer application in the tropics: II. Risks and opportunities for smallholders cultivating maize on Kenya's arable land. Agric. Syst. 1997, 53, 69-95. [CrossRef]

39. Keating, B.A.; Wafula, B.M.; Watiki, J.M.; Karanja, D.R. Dealing with Climatic Risk in Agricultural ResearchA Case Study Modelling Maize in Semi-arid Kenya. In Soil Fertility and Climatic Constraints in Dryland Agriculture; Craswell, E.T., Simpson, J., Eds.; ACIAR: Harare, Zimbabwe, 1993; pp. 105-114.

40. McCown, R.L.; Wafula, B.M.; Mohammed, L.; Ryan, J.G.; Hargreaves, J.N.G. Assessing the value of a seasonal rainfall predictor to agronomic decisions: The case of response farming in Kenya. In Climatic Risk in Crop 
Production. Models and Management for the Semi-Arids Tropics and Subtropics; Muchow, R.C., Bellamy, J.A., Eds.; CAB Internatioanl: Wallingford, UK, 1991; pp. 383-409.

41. R Development Core Team. R: A language and Environment for statistical computing. In $R$ Foundation for Statistical Computing; R Core Team: Vienna, Austria, 2017.

42. McIntosh, M.S. Analysis of combined experiments. Agron. J. 1983, 75, 153-155. [CrossRef]

43. Stals, H.; Inzé, D. When plant cells decide to divide. Trends Plant Sci. 2001, 6, 359-364. [CrossRef]

44. Vanderlip, R.L. How a Sorghum Plant Develops; Kansas State University: Manhattan, KS, USA, 1993.

45. Kante, M.; Rattunde, H.F.W.; Leiser, W.L.; Nebié, B.; Diallo, B.; Diallo, A.; Touré, A.O.; Weltzien, E.; Haussmann, B.I.G. Can tall guinea-race sorghum hybrids deliver yield advantage to smallholder farmers in West and Central Africa? Crop Sci. 2017, 57, 833-842. [CrossRef]

46. Ndiaye, M.; Adam, M.; Muller, B.; Guissé, A.; Cissé, N. Performances agronomiques et stabilité phénotypique de génotypes de Sorgho (Sorghum bicolor L. Moench) au Sénégal : Une étude des interactions génotypes-environnement. J. Appl. Biosci. 2018, 125, 12617-12629. [CrossRef]

47. Ndiaye, M. Modélisation D'idéotypes Variétaux de Sorgho (Sorghum bicolor L. Moench) Sur la Base de la Caractérisation du Fonctionnement et du Potentiel de Sorghos Multi-Usage au Sénégal et Utilisation Pour Raisonner Des Choix Variétaux en Relation aux Environnemen; Cheikh Anta Diop: Dakar, Sénégal, 2018.

48. Sitthaphanit, S.; Limpinuntana, V.; Toomsan, B.; Panchaban, S.; Bell, R.W. Growth and yield responses in maize to split and delayed fertilizer applications on sandy soils under high rainfall regimes. Kasetsart J. 2010, 44, 991-1003.

49. Woolfolk, C.W.; Raun, W.R.; Johnson, G.V.; Thomason, W.E.; Mullen, R.W.; Wynn, K.J.; Freeman, K.W. Influence of late-season foliar nitrogen application on yield and grain nitrogen in winter wheat. Agron. J. 2002, 94, 429-434. [CrossRef]

50. Sanz Rozas, H.R.; Echeverria, H.E.; Barbieri, P.A. Nitrogen balance as affected by application time and nitrogen fertilizer rate in irrigated no-tillage maize. Agron. J. 2004, 96, 1622-1631. [CrossRef]

(C) 2019 by the authors. Licensee MDPI, Basel, Switzerland. This article is an open access article distributed under the terms and conditions of the Creative Commons Attribution (CC BY) license (http://creativecommons.org/licenses/by/4.0/). 